\title{
Visual analogue scale. A simple tool for daily treatment monitoring in allergic rhinitis
}

\author{
Wizualna skala analogowa - proste narzędzie do codziennego monitorowania leczenia \\ alergicznego nieżytu nosa
}

\author{
'Department of Environmental Hazard Prevention and Allergology, Medical University of Warsaw, Warsaw, Poland \\ ${ }^{2}$ Department of Paediatrics and Neonatology, Central Clinical Hospital of the Ministry of the Interior, Warsaw, Poland \\ Correspondence: Professor Adam J. Sybilski, MD PhD, Department of Paediatric and Neonatology, Central Clinical Hospital of the Ministry of the Interior, Wołoska 137, 02-507 Warsaw, Poland, \\ tel.: +4822 508 12 20, e-mail: adam.sybilski@cskmswia.pl
}

Abstract In patients with allergic rhinitis, continuous assessment and monitoring of symptom severity, their nature and changes depending on the place, time and situation in which they occur are essential. Symptoms of allergic rhinitis are often subjective, and difficult to assess and verify. Individualised therapy and continuous monitoring of the disease create the need for a simple and effective tool. Visual analogue scale (VAS) is an instrument that can be used in daily practice. VAS is usually a horizontal $100 \mathrm{~mm}$ long scale with two opposing descriptors at its end points. Patients with allergic rhinitis specify a point on the scale that best corresponds to the severity of their symptoms. Symptoms of allergic rhinitis can be assessed globally or separately on different scales (nasal obstruction, rhinorrhoea, itching, sneezing). Advantages of VAS include: possibility to distinguish minimal differences in symptom severity, simplicity and easy interpretation, which translate into reproducibility, uniform evaluation system and high patient acceptance. VAS is well correlated with the Allergic Rhinitis and its Impact on Asthma classification, and a score of 50 (in a $100 \mathrm{~mm}$ scale) indicates moderate and severe allergic rhinitis. It has been shown that, irrespective of a baseline VAS score, a $23 \mathrm{~mm}$ improvement indicates that treatment has been effective, while a $30 \mathrm{~mm}$ improvement is associated with an improvement of the quality of life parameters. The scale is particularly useful for the purposes of documentation of allergic rhinitis severity and disease control in everyday practice due to its simplicity, timeeffectiveness and low susceptibility to errors, especially when combined with modern communication technologies, such as smartphone applications.

Key words: visual analogue scale, allergic rhinitis, monitoring, work-up

W prowadzeniu pacjenta $\mathrm{z}$ alergicznym nieżytem nosa niezbędne są stała ocena i monitorowanie nasilenia objawów, ich charakteru oraz zmiany w zależności od miejsca, czasu i sytuacji, w której występują. Objawy alergicznego nieżytu nosa są często subiektywne, trudne od oceny i weryfikacji. Indywidualizacja terapii i możliwie stałe kontrolowanie choroby wymuszają konieczność posiadania prostego, łatwego w użyciu i skutecznego narzędzia. Takim „urządzeniem” do codziennego stosowania jest wizualna skala analogowa (visual analogue scale, VAS). VAS to zazwyczaj pozioma linia o długości $100 \mathrm{~mm}$ ze skrajnymi określeniami na obu końcach. Pacjenci z alergicznym nieżytem nosa zaznaczają punkt na linii, który najlepiej odpowiada nasileniu ich objawów. Symptomy alergicznego nieżytu nosa można oceniać zbiorczo lub każdy objaw osobno na oddzielnej skali (blokada nosa, wodnisty wyciek, świąd, kichanie). Do zalet VAS należą między innymi: możliwość odróżnienia minimalnych różnic w nasileniu objawów, prostota i szybkość w użyciu i interpretacji, co pozwala na powtarzalność, ujednolicony system oceny i duża akceptacja pacjentów. Skala VAS dobrze koreluje z klasyfikacją Allergic Rhinitis and its Impact on Asthma, a wynik 50 (w skali $100 \mathrm{~mm}$ ) wskazuje na umiarkowany i ciężki alergiczny nieżyt nosa. Dla alergicznego nieżytu nosa wykazano, że niezależnie od wyjściowego wyniku VAS poprawa o $23 \mathrm{~mm}$ świadczy o skutecznym leczeniu, a poprawa o $30 \mathrm{~mm}$ zawsze wiązała się z poprawą parametrów jakości życia. Skala jest szczególnie przydatna do dokumentowania nasilenia i ciężkości objawów alergicznego nieżytu nosa oraz kontroli choroby w codziennym postępowaniu, z uwagi na prostotę, oszczędność czasu i niską podatność na błędy, zwłaszcza w połączeniu z nowoczesnymi technologiami komunikacyjnymi, takimi jak aplikacje na smartfony. 
A detailed and thorough patient's history as well as physical examination are the basis of the diagnostic process in allergology. In patients with allergic rhinitis (AR), continuous assessment and monitoring of symptom severity, their nature and changes depending on the place, time and situation in which they occur are essential. AR symptoms are often subjective, and difficult to assess and verify. A diagnosis is based on these symptoms, and their objectification is impossible (Tab. 1) ${ }^{(1-5)}$.

Moreover, AR symptoms vary from patient to patient in terms of their nature, severity and duration. AR can be divided into four types (Fig. 1), and their definition is very precise and based on symptom duration and their effect on patient functioning (Tab. 2) ${ }^{(6)}$. A temporal criterion involves a four-week duration, and the severity assessment is conducted on the basis of four parameters: impact on sleep, learning and working, daily activity, and patient functioning. In this classification, an allergen or allergens that induce the symptoms are irrelevant. This division is in an ideal correlation with symptom severity and their effect on the quality of life in children ${ }^{(1,2,5)}$.

At present, attempts are being made at individualising therapy and, possibly, continuous monitoring of the disease. Moreover, the determination of AR phenotype (Tab. 3 ) is also significant in daily practice as it is highly helpful in therapy selection. In disease monitoring, it is essential to achieve reliable and reproducible information about treatment efficacy (symptoms before and after the use of given drugs) ${ }^{(7,8)}$. All of this entails the necessity to possess a simple and effective tool to objectify symptoms and monitor disease severity. Visual analogue scale (VAS) seems to be an instrument fit for daily use. It is a psychometric scale used to evaluate a variable and subjective trait or attitude (e.g. AR symptoms) that

AR is defined as rhinitis, usually chronic and lgE-dependent, induced by environmental allergens.

AR diagnosis is based on the presence of at least two typical symptoms:

- nasal obstruction

- rhinorrhoea (also secretion running down the posterior pharynx)

- itching

- sneezing

occurring for more than an hour a day for more than 2 weeks in a year.

Tab. 1. AR definition

- 4 types

- 4-week duration

- 4 parameters of symptom severity

Tab. 2. The "Great 4" principle in AR division

\begin{tabular}{|c|c|c|}
\hline Division criterion & \multicolumn{2}{|c|}{ Phenotypes of allergic rhinitis } \\
\hline Duration of symptoms & Intermittent & Persistent \\
\hline Severity of symptoms & Mild & Moderate/severe \\
\hline Nature of symptoms & Obstruction & Secretion \\
\hline Type of sensitivity & Monovalent & Polyvalent \\
\hline Organ involvement & Single organ & Many organs \\
\hline Degree of disease control & Controlled & Uncontrolled \\
\hline
\end{tabular}

Tab. 3. AR phenotypes

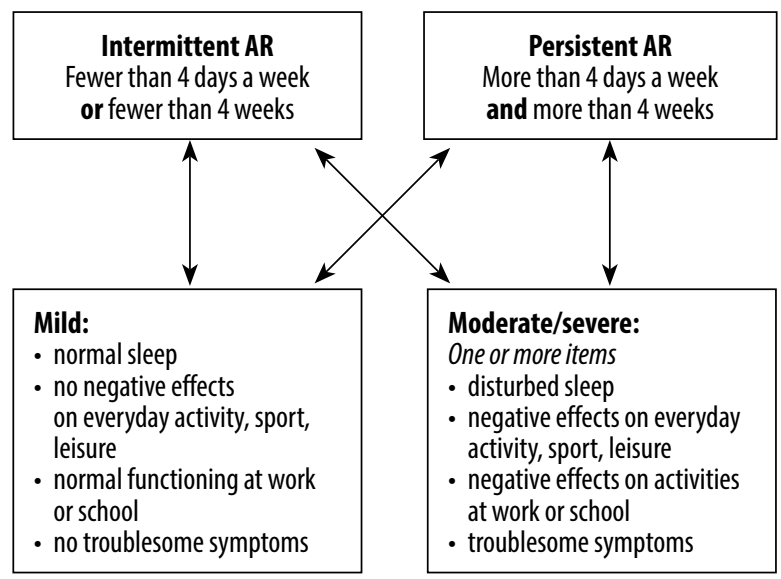

Fig. 1. ARIA classification of $A R$

may change continuously and be impossible to measure accurately with available tools. VAS was first presented and used in 1921, and has been successfully employed in medicine, psychology and market research ever since ${ }^{(9)}$.

\section{PRACTICAL APPLICATION OF VISUAL ANALOGUE SCALE FOR ALLERGIC RHINITIS}

VAS is usually a horizontal $100 \mathrm{~mm}$ long line with descriptors at its ends expressing two extremes of a feeling. AR patients mark a point that best corresponds to the severity of their symptoms or current status of disease control. For this purpose, the patient or parent is instructed to put a cross on the straight line at a point that best corresponds to their feelings concerning AR. Thanks to the continuous response format, the patient is not limited to a fixed number of potential responses. Instead, his or her answers can be marked at any point on the scale, and represent systematic gradation of disease severity ${ }^{(9)}$.

The respondent's cross is then assigned a score from 0 to 100. If documented in the paper version, the results may be presented in millimetres. This marking and division into 100 units is considered sufficiently sensitive. The results can also be archived electronically. When using this option, the analysis is usually automatic using a special algorithm ${ }^{(10)}$. When selecting end points (0-100), it is important to present maximum extremes of symptom severity in order to encompass the entire spectrum of various feelings, and not only their part (Tab. 4).

\footnotetext{
- Congestion: 0 - free breathing; 100 - complete obstruction at day and night

- Rhinorrhoea: 0 - dry nose all day; 100 - continuous secretion (wiping the nose many times in one hour)

- Itching: 0 - no itching; 100 - persistent itching disrupting everyday activities

- Sneezing: 0 - no sneezing; 100 - persistent sneezing fits for the whole day and night that disrupt normal functioning
}

Tab. 4. Example end points of the VAS scale for individual $A R$ symptoms 
AR symptoms can be assessed globally (together) or separately on different scales (nasal congestion, rhinorrhoea, itching, sneezing). Currently, VAS also enables the assessment of the impact of AR on the course of asthma.

VAS should not have any markings (e.g. to signify the central point or divide the scale into equal fragments) as its sensitivity without markings is higher. However, the most significant element of each VAS is the question rather than the line. The line always remains the same, whilst the question may change $\mathrm{e}^{(9)}$.

\section{ADVANTAGES OF VISUAL ANALOGUE SCALE}

The commonness of VAS results from its many advantages in the assessment of disease symptoms. Tab. 5 presents the most important pluses ${ }^{(9)}$.

\section{DISADVANTAGES AND CHALLENGES ASSOCIATED WITH VISUAL ANALOGUE SCALE}

The primary practical disadvantage of VAS is the necessity to make accurate measurements in millimetres. Moreover, the VAS system can be used in the written (or digital) form only, and not verbally. Also, VAS requires at least minimal patient's visual skill and hand-eye coordination. This is of significance in children, where parents' help becomes important. However, assuming that the responses are each time made by the same parent based on his or her subjective judgement, this analysis can be very helpful in the monitoring of the disease and its treatment. One of the reservations concerning the scale is that patients find it difficult to select a point that best corresponds to their symptoms.

\begin{tabular}{|l|l|}
\hline Feature & Advantage \\
\hline High resolution (0-100 mm) & $\begin{array}{l}\text { Possibility to distinguish minimal } \\
\text { differences in disease severity }\end{array}$ \\
\hline Preferred by patients' & Patients' acceptance \\
\hline Reproducibility & $\begin{array}{l}\text { Simple evaluation of changes in disease } \\
\text { severity }\end{array}$ \\
\hline $\begin{array}{l}\text { Uniform system of application } \\
\text { and interpretation }\end{array}$ & $\begin{array}{l}\text { The same assessment by different doctors, } \\
\text { nurses and patients }\end{array}$ \\
\hline $\begin{array}{l}\text { Simplicity and readiness } \\
\text { for use and interpretation }\end{array}$ & $\begin{array}{l}\text { Possibility of daily, routine use in any } \\
\text { conditions and places }\end{array}$ \\
\hline Routine use & $\begin{array}{l}\text { Positive effects on patient behaviour } \\
\text { and adjustment to lifestyle to relieve } \\
\text { symptoms }\end{array}$ \\
\hline Linear scale & $\begin{array}{l}\text { Values obtained in VAS are more accurate } \\
\text { than those of a categorical scale. This type } \\
\text { of scale is believed to be more accurate and } \\
\text { sensitive, and less prone to distortion } \\
\text { and bias than a categorical scale }\end{array}$ \\
\hline $\begin{array}{l}\text { Particularly well-suited } \\
\text { for continuous features } \\
\text { and accuracy }\end{array}$ & $\begin{array}{l}\text { AR symptoms are inherently continuous, } \\
\text { which makes it necessary to perform } \\
\text { various assessments of disease severity }\end{array}$ \\
\hline & $\begin{array}{l}\text { Possibility of making objective judgement } \\
\text { based on VAS results }\end{array}$ \\
\hline
\end{tabular}

Tab. 5. Features and advantages of $V A S^{(9)}$
It is difficult for them to evaluate the precise distance from the initial or final points. This occurs particularly at the first use. As has already been mentioned, the question should be as detailed as possible, and the anchor points precise ${ }^{(9)}$.

\section{VISUAL ANALOGUE SCALE AS AN INSTRUMENT IN THE WORK-UP OF AR}

Objective assessment of nasal obstruction can be made with the use of peak flow meters, acoustic rhinometry or rhinomanometry ${ }^{(2-5)}$. Unfortunately, these tools are not commonly available in daily practice of family doctors or paediatricians. Additionally, a significant number of patients take drugs and select doses on their own. That is why another sensitive tool, which correlates well with disease severity and can be implemented in various situations, should be used for everyday assessment in AR. It seems that VAS meets all these criteria ${ }^{(11)}$. Although the results of VAS in AR are not significantly different in terms of sensitivity and reproducibility from other psychometric tests utilising categorical scales, a number of studies have found it to be superior in terms of simplicity and resolution.

Since VAS presents even minimal changes, which are sometimes more challenging to interpret than grades on categorical scales, it is significant to determine the threshold from which they are deemed significant. There are a number of studies and data addressing this issue ${ }^{(9)}$.

A score of 50 (in a $100 \mathrm{~mm}$ scale) indicates moderate and severe AR (Fig. 2) in most studies ${ }^{(12-14)}$, but one has determined a threshold value at $60 \mathrm{~mm}^{(15)}$. Moreover, VAS correlates well with the Allergic Rhinitis and its Impact on Asthma (ARIA) classification (Fig. 1) ${ }^{(16-18)}$. It has also been observed that treatment-induced improvement, represented in VAS as a score below $50 \mathrm{~mm}$, correlates well with normalised Rhinoconjunctivitis Quality of Life Questionnaire (RQLQ) and Work Productivity and Activity Impairment Allergic Specific (WPAI-AS) Questionnaire ${ }^{(19)}$. Patients with scores over $50 \mathrm{~mm}$ still exhibited abnormal values in terms of quality of life and work productivity ${ }^{(19)}$. It has been shown that, irrespective of the baseline VAS score, a $23 \mathrm{~mm}$ improvement indicates that treatment has been effective ${ }^{(20)}$. Moreover, a $30 \mathrm{~mm}$ improvement has always been associated with an improvement of the quality of life parameters ${ }^{(11,20)}$. On the other hand, patients receiving placebo declared a $10 \mathrm{~mm}$ improvement only ${ }^{(21,22)}$.

The document called MACVIA-ARIA (European platform for AR patients) ${ }^{(23)}$, which is recommended by the Polish Society of Allergology, defines three grades of AR control: - >50: uncontrolled AR;

- 20-50: partially controlled AR;

- <20: well-controlled $\mathrm{AR}^{(11,20)}$.

VAS has also been used as an evaluation parameter in double-blind placebo-controlled studies. In two large trials evaluating outcomes of AR treatment with antihistamines, VAS better represented self-assessment of patients receiving placebo and verum than total analysis of symptoms ${ }^{(21,22)}$. 

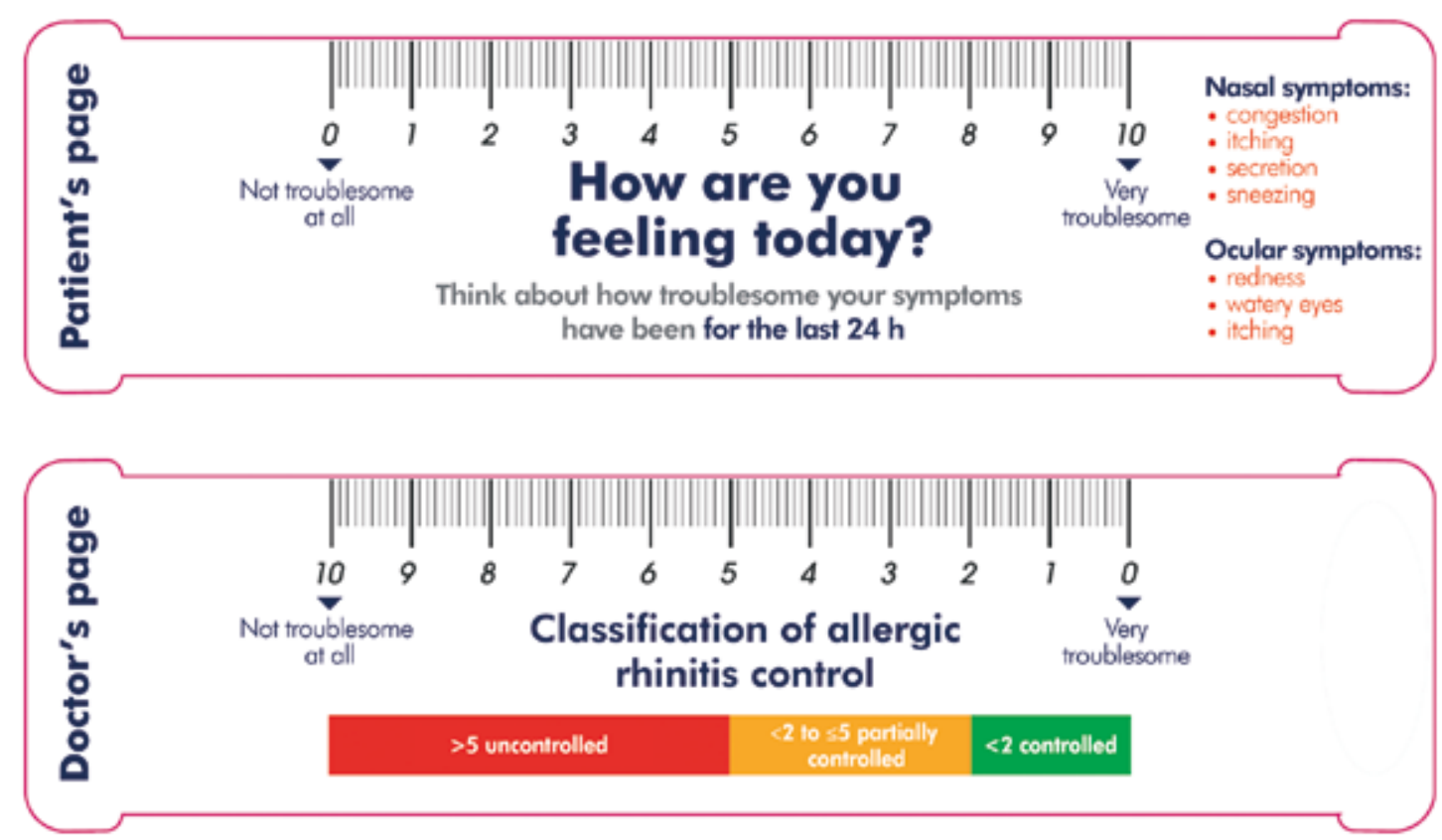

Fig. 2. VAS and its usage

VAS has also been successfully used in real-life research and observational studies ${ }^{(24-26)}$.

It has been demonstrated that VAS in AR can be used in each age group, including preschool children (with their parents' help) $)^{(27)}$ and elderly patients ${ }^{(28)}$.

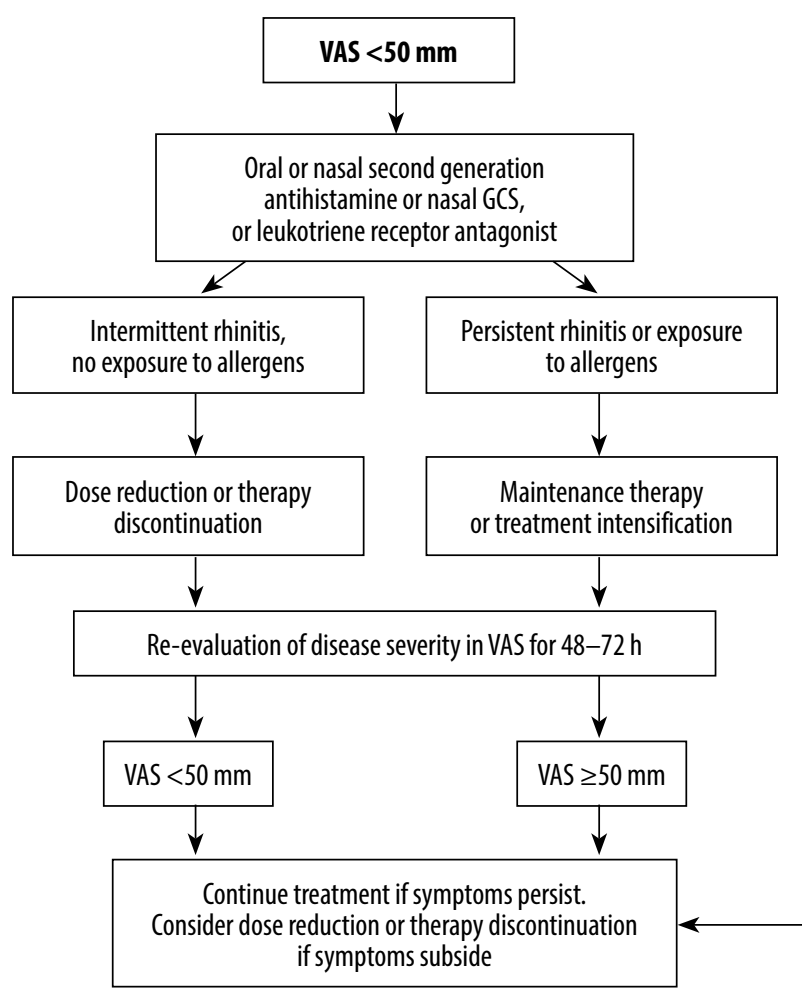

Moreover, VAS has been validated for various languages (e.g. German, French, English, Spanish and Japanese).

VAS results can help control and modify AR treatment in everyday practice. The MACVIA document proposes an algorithm to control AR based on a VAS score (Fig. 3) ${ }^{(29)}$.

GCS - glucocorticosteroid; AIT - allergen immunotherapy.

Fig. 3. AR control algorithm based on the VAS score according to the MACVIA ${ }^{(29)}$ 


\section{CONCLUSIONS}

VAS is a useful method for the documentation of symptoms and assessment of AR control. It is also an alternative to other psychometric scales.

The scale is particularly useful for the purposes of documentation of AR severity and control in everyday practice due to its simplicity, time-effectiveness and low susceptibility to errors. When combined with modern communication technologies, such as smartphone applications or a vehicle alarm system, it is a valuable tool for documentation of AR severity, treatment efficacy and disease control.

\section{Conflict of interest}

Author does not report any financial or personal connections with other persons or organisations, which might negatively affect the contents of this publication and/or claim authorship rights to this publication.

\section{References}

1. Wise SK, Lin SY, Toskala E et al.: International Consensus Statement on Allergy and Rhinology: Allergic Rhinitis. Int Forum Allergy Rhinol 2018; 8: 108-352.

2. Roberts G, Xatzipsalti M, Borrego LM et al.: Paediatric rhinitis: position paper of the European Academy of Allergy and Clinical Immunology. Allergy 2013; 68: 1102-1116.

3. Bousquet J, Khaltaev N, Cruz AA et al.; World Health Organization; GA2 LEN; AllerGen: Allergic Rhinitis and its Impact on Asthma (ARIA) 2008 update (in collaboration with the World Health Organization, GA ${ }^{2}$ LEN and AllerGen). Allergy 2008; $63 \mathrm{Suppl}$ 86: 8-160.

4. Wallace DV, Dykewicz MS, Bernstein DI et al.; Joint Task Force on Practice; American Academy of Allergy; Asthma \& Immunology; American College of Allergy; Asthma and Immunology; Joint Council of Allergy, Asthma and Immunology: The diagnosis and management of rhinitis: an updated practice parameter. J Allergy Clin Immunol 2008; 122 (Suppl): S1-S84.

5. Samoliński B, Arcimowicz M (eds.): Polskie Standardy Leczenia Nieżytów Nosa (PoSLeNN). Stanowisko Panelu Ekspertów Polskiego Towarzystwa Alergologicznego. Alergologia Polska 2013; S1: 1-167.

6. Sybilski AJ: Alergiczny nieżyt nosa - kicham na katar. In: Sybilski AJ: Choroby alergiczne u dzieci. Medical Education, Warszawa 2018: 43-57.

7. Papadopoulos NG, Bernstein JA, Demoly P et al.: Phenotypes and endotypes of rhinitis and their impact on management: a PRACTALL report. Allergy 2015; 70: 474-494.

8. Papadopoulos NG, Guibas GV: Rhinitis subtypes, endotypes, and definitions. Immunol Allergy Clin North Am 2016; 36: 215-233.

9. Klimek L, Bergmann KC, Biedermann $\mathrm{T}$ et al.: Visual analogue scales (VAS): measuring instruments for the documentation of symptoms and therapy monitoring in cases of allergic rhinitis in everyday health care: Position Paper of the German Society of Allergology (AeDA) and the German Society of Allergy and Clinical Immunology (DGAKI), ENT Section, in collaboration with the working group on Clinical Immunology, Allergology and Environmental Medicine of the German Society of Otorhinolaryngology, Head and Neck Surgery (DGHNOKHC). Allergo J Int 2017; 26: 16-24.
10. Aitken RC: Measurement of feelings using visual analogue scales. Proc R Soc Med 1969; 62: 989-993.

11. Bousquet PJ, Combescure C, Klossek JM et al.: Change in visual analog scale score in a pragmatic randomized cluster trial of allergic rhinitis. J Allergy Clin Immunol 2009; 123: 1349-1354.

12. Baiardini I, Braido F, Brandi S et al.: The impact of GINA suggested drugs for the treatment of asthma on Health-Related Quality of Life: a GA²LEN review. Allergy 2008; 63: 1015-1030.

13. Bousquet PJ, Demoly P, Devillier P et al.: Impact of allergic rhinitis symptoms on quality of life in primary care. Int Arch Allergy Immunol 2013; 160: 393-400.

14. Yamamoto H, Yamada T, Sakashita $M$ et al.: Efficacy of prophylactic treatment with montelukast and montelukast plus add-on loratadine for seasonal allergic rhinitis. Allergy Asthma Proc 2012; 33: e17-e22.

15. Larenas-Linnemann D, Dinger H, Shah-Hosseini K et al.; Mexican Study Group on Allergic Rhinitis and SPT Sensitivity: Over diagnosis of persistent allergic rhinitis in perennial allergic rhinitis patients: a nationwide study in Mexico. Am J Rhinol Allergy 2013; 27: 495-501.

16. Bousquet PJ, Bousquet-Rouanet L, Co Minh HB et al.: ARIA (Allergic Rhinitis and Its Impact on Asthma) classification of allergic rhinitis severity in clinical practice in France. Int Arch Allergy Immunol 2007; 143: 163-169.

17. del Cuvillo A, Montoro J, Bartra J et al.: Validation of ARIA duration and severity classifications in Spanish allergic rhinitis patients - the ADRIAL cohort study. Rhinology 2010; 48: 201-205.

18. Ohta K, Bousquet PJ, Aizawa $\mathrm{H}$ et al.: Prevalence and impact of rhinitis in asthma. SACRA, a cross-sectional nation-wide study in Japan. Allergy 2011; 66: 1287-1295.

19. Bousquet PJ, Bachert C, Canonica GW et al.: Uncontrolled allergic rhinitis during treatment and its impact on quality of life: a cluster randomized trial. J Allergy Clin Immunol 2010; 126: 666-668.e5.

20. Demoly P, Bousquet PJ, Mesbah K et al.: Visual analogue scale in patients treated for allergic rhinitis: an observational prospective study in primary care: asthma and rhinitis. Clin Exp Allergy 2013; 43: 881-888.

21. Bousquet J, Bachert C, Canonica GW et al.; ACCEPT-1 study group: Efficacy of desloratadine in intermittent allergic rhinitis: a GA ${ }^{2}$ LEN study. Allergy 2009; 64: 1516-1523.

22. Bousquet J, Bachert C, Canonica GW et al.; ACCEPT-2 Study Group: Efficacy of desloratadine in persistent allergic rhinitis a GA ${ }^{2} L E N$ study. Int Arch Allergy Immunol 2010; 153: 395-402.

23. Bousquet J, Schunemann HJ, Fonseca J et al.: MACVIA-ARIA Sentinel NetworK for allergic rhinitis (MASK-rhinitis): the new generation guideline implementation. Allergy 2015; 70: 1372-1392.

24. Bousquet J, Lund VJ, van Cauwenberge P et al.: Implementation of guidelines for seasonal allergic rhinitis: a randomized controlled trial. Allergy 2003; 58: 733-741.

25. Bousquet J, Bodez T, Gehano P et al.: Implementation of guidelines for allergic rhinitis in specialist practices. A randomized pragmatic controlled trial. Int Arch Allergy Immunol 2009; 150: 75-82.

26. Klimek L, Bachert C, Mösges R et al.: Effectiveness of MP29-02 for the treatment of allergic rhinitis in real-life: results from a noninterventional study. Allergy Asthma Proc 2015; 36: 40-47.

27. Morais-Almeida M, Santos N, Pereira AM et al.: Prevalence and classification of rhinitis in preschool children in Portugal: a nationwide study. Allergy 2013; 68: 1278-1288

28. Morais-Almeida M, Pite H, Pereira AM et al.: Prevalence and classification of rhinitis in the elderly: a nationwide survey in Portugal. Allergy 2013; 68: 1150-1157.

29. Bousquet J, Schünemann HJ, Hellings PW et al.; MASK study group: MACVIA clinical decision algorithm in adolescents and adults with allergic rhinitis. J Allergy Clin Immunol 2016; 138: 367-374.e2 